\title{
ANALISIS PERBANDINGAN MODEL KONTRAK APBN DAN APBD TERHADAP MODEL KONTRAK FIDIC
}

\author{
oleh : \\ Ediyanto Arief \\ Teknik Sipil Universitas Mercu Buana \\ Email : ediyanto91@gmail.com \\ Sarwono Hardjomuljadi \\ Teknik Sipil Universitas Mercu Buana \\ Email : sarwonohm2@gmail.com
}

\begin{abstract}
Abstrak : Pemerintah Indonesia menginvestasikan ratusan triliun rupiah setiap tahun dalam membangun infrastruktur. Kontrak konstruksi adalah salah satu jaminan untuk memastikan keberhasilan proyek, oleh karena itu klausula-klausulanya harus efisien, adil dan berimbang. Makalah ini terdiri dari perbandingan Syarat-Syarat Umum Kontrak (SSUK) APBN dan APBD terhadap model kontrak FIDIC General Conditions of Contract (GCC) 1999. Selain itu bertujuan untuk menganalisis sepuluh penyebab utama klaim yang sering terjadi pada proyek konstruksi di Provinsi Banten. Kemudian mencocokkan penyebab klaim pada SSUK APBN dan APBD, yang kemudian dibandingkan dengan FIDIC GCC. Metodologi yang digunakan untuk menentukan penyebab klaim tertinggi adalah Relative Important Index (RII). Analisis perbandingan menggunakan Metodologi Multistep. Berdasarkan hasil analisis faktor, ditemukan sepuluh faktor dominan yang menyebabkan klaim di Provinsi Banten, dengan tiga tertinggi : 1) ketersediaan dan kepemilikan lahan kerja, 2) ambigu dalam memaknai klausula kontrak, 3) perubahan desain. Hasil analisis menunjukkan bahwa FIDIC GCC adalah kontrak yang paling efisien, adil, dan seimbang terhadap manajemen klaim. Berdasarkan hasil penelitian, disarankan untuk mengadopsi model kontrak FIDIC karena memiliki keuntungan pada sebagian besar aspek sebagai model kontrak konstruksi Indonesia.
\end{abstract}

Kata Kunci : Kontrak Konstruksi, FIDIC General Conditions of Contract, RII, Analisis Perbandingan, Model Kontrak

Abstract : The Indonesian government is investing billions of dollars every year in new facilities to improve the infrastructure of the country. Construction contracts as the first guarantee to ensure the success on going of the project, therefore have the duty to be formed properly. The paper consists of a General Conditions comparison between the Indonesian Budget and Regional Government Budget Model contracts to the Fidic (Fe'de'ration Internationale des Inge'nieurs-Conseils) 1999 suite of contracts. This paper aims to analyze the top ten causes of the most common claims on construction projects in the Province of Banten. Then match the causes of the claims on general conditions of contracts the Indonesian Budget and and Regional Government Budget Model contracts, which are then compared with the FIDIC GCC. The methodology used to find the causes of the highest claim is Relative Important Index (RII). Then for comparison analysis a Multistep Methodology was utilized. Based on the results of the factor analysis, ten dominant factors causing claims in Province Banten, the three highest were found Namely: 1) Possession of Site and Availability, 2) Ambiguisties In Contract Document, 3) Changes in Design. The result of the analysis showed that FIDIC GCC is the most efficient, fair, and balanced contract regarding the claims management. Based on the result, it's suggested to adopt the FIDIC contracts as it has large advantages in most of the aspects of which Indonesian contracts is shorting.

Keywords : Construction Contracts, FIDIC General Conditions of Contract, RII, Comparison Analysis, Contract Model 


\section{Pendahuluan}

Pelaksanaan industri konstruksi di Indonesia, yang menggunakan dana Anggaran Pendapatan dan Belanja Negara (APBN) dan Anggaran Pendapatan dan Belanja Daerah (APBD) dilakukan melalui proses pelelangan barang dan jasa oleh pemerintah sebagai pengguna jasa. Proyekproyek konstruksi dengan biaya dari pemerintah (APBN dan APBD) menggunakan standar kontrak yang mengacu ke Undang-Undang Republik Indonesia No 2 Tahun 2017 Tentang Jasa Konstruksi dan Peraturan Presiden Republik Indonesia Nomor 16 Tahun 2018 Tentang Pengadaan Barang/Jasa Pemerintah serta Peraturan Menteri yang terkait.

Menurut Sarwono Hardjomuljadi (2014:2) penggunaan standar persyaratan umum kontrak akan menghemat biaya dan waktu yang signifikan. Standar general conditions of contract yang adil dan berimbang akan sangat mendukung perkembangan dunia jasa konstruksi terutama sebagai salah satu sarana pembinaan kontraktor dalam negeri. Penggunaan standar general conditions of contract dalam hal ini FIDIC Conditions of Contract bagi semua kontrak konstruksi sektor publik di Indonesia tidak hanya berdampak positif bagi pengguna jasa tetapi juga bagi penyedia jasa karena penyedia jasa juga tidak perlu setiap kali membaca dan mempelajari kembali general conditions of contract untuk setiap proyek dengan pengguna jasa yang berbeda mengingat semuanya menggunakan standar general conditions of contract yang sama. Selain itu, kompetensi dan ketersediaan tenaga ahli yang relatif rendah, aspek resiko yang belum diperhitungkan, ditambah peran konsultan perencana yang belum optimal. Di lapangan jumlah tenaga pengawas masih terbatas, pembagian peran dan tanggung jawab pengawas pun tidak optimal, di tambah remunerasi tenaga kerja konstruksi yang belum sesuai, peralatan dan material yang tidak sesuai dengan spesifikasi dan sistem operasional prosedur belum dijalankan sesuai aturan.

\section{Rumusan Masalah}

1. Apakah penyebab klaim konstruksi yang paling sering terjadi pada proyek APBN dan APBD?

2. Apakah pasal-pasal pada model kontrak APBN dan APBD yang terkait dengan klausula-klausula FIDIC Conditions of Contract?

\section{Tujuan Penelitian}

Mengidentifikasi penyebab klaim konstruksi tertinggi di Provinsi Banten, lalu mencocokkan sepuluh (10) tertinggi penyebab klaim tersebut dengan klausulaklausula pada Syarat-Syarat Umum Kontrak (SSUK) APBN dan APBD. Selanjutnya dibandingkan terhadap klausula-klausula FIDIC general conditions of contract. Analisa perbandingan ini menghasilkan kesimpulan bahwa model kontrak mana yang dinilai lebih adil, berimbang, dan efektif yang sesuai dengan tujuan penyelenggaraan proyek konstruksi. Selain itu menganalisa apakah Model kontrak FIDIC dapat dipakai sebagai model kontrak untuk kegiatan yang dibiayai oleh APBN dan APBD.

\section{Kontrak Konstruksi (Construction Contract)}

Menurut Sarwono (2017) "Pelaksanaan pekerjaan konstruksi besar milik institusi pemerintah, diantaranya Kementerian maupun BUMN dikerjakan oleh pihak lain yang ditunjuk sebagai penyedia jasa kontraktor melalui suatu kontrak konstruksi, yang dalam pelaksanaannya 
hampir semua konstruksi mengacu pada FIDIC Conditions of Contract sebagai suatu "model law", oleh karena itu pemahaman tentang kontrak konstruksi, manajemen klaim dan penyelesaian sengketa konstruksi pada umumnya dan model kontrak konstruksi yang diterbitkan oleh Federation International Des Ingenieurs-Conseils (FIDIC) yang berkedudukan di Geneva-Switzerland, merupakan syarat mutlak keberhasilan pekerjaan konstruksi.

Aspek legal kontrak konstruksi di Indonesia bersumber pada hukum kontrak yang berlaku di Indonesia. Hukum perihal perjanjian ini tertuang dalam Kitab UndangUndang Hukum Perdata (KUH Perdata) Buku III tentang perikatan. Selain itu hukum kontrak konstruksi secara spesifik diatur dalam Undang-Undang Jasa Konstruksi (UUJK), yaitu UU no 2 Tahun 2017 Tentang Jasa Konstruksi yang berlaku untuk seluruh proyek konstruksi di Indonesia.

\section{Persyaratan Umum Kontrak FIDIC (FIDIC General Conditions of Contract)}

FIDIC adalah suatu organisasi yang dikenal diseluruh dunia karena telah menerbitkan standar persyaratan umum kontrak (conditions of contract) yang dikenal sebagai suatu conditions of contract yang fair and balance. Hingga saat ini bahkan orang menyebut Conditions of Contract for Construction (1999), yang merupakan pengembangan dari FIDIC Conditions of Contract for Works of Civil Engineering Construction (1987), yang juga merupakan conditions of contract yang tertua dari keluarga standar persyaratan umum kontrak yang dibuat oleh FIDIC, sebagai"FIDIC" saja.

Menurut Miroslaw dan A.J Clark," Ketika Ketentuan Kontrak yang baru ini disusun, FIDIC mencoba menghadirkan yang terbaik sehingga "Persyaratan" dapat diterapkan tidak hanya pada sistem Common Law (yaitu Sistem Hukum Anglo-Amerika), tetapi juga dapat digunakan pada sistem Civil Law. Untuk mencapai hal ini, kelompok kerja kontrak meninjau kembali klausa, sehingga mereka dapat diterapkan berdasarkan dua undang-undang yang disebutkan di atas. Edisi baru ini juga menunjukkan lebih banyak fleksibilitas dan kemampuan beradaptasi. Misalnya, dalam edisi lama, jaminan kinerja bersyarat diperlukan, yang berbeda dari Bank Dunia. Sementara dalam edisi baru, formulir jaminan ditetapkan oleh "Persyaratan Khusus" yang dapat diterapkan agar pemberi kerja lebih fleksibel.

\section{Persyaratan Umum Kontrak Konstruksi di Indonesia}

Persyaratan umum kontrak bidang konstruksi di Indonesia untuk sektor publik maupun swasta masih dibuat secara tailor made dan belum distandarisasi, sehingga bahkan untuk suatu kontrak yang dikatakan berdasarkan FIDIC Condtions of Contract, pada kenyataannya adalah suatu FIDIC Condtions of Contract yang sudah dimutilasi (mutilated), yang tentunya sudah tidak lagi ber"jiwa" FIDIC Condtions of Contract yang adil dan berimbang. Suatu kegiatan pelaksanaan proyek yang didasari kontrak konstruksi, sangat dinamis dan tak tentu (uncertain) bahkan risiko pada suatu proyek konstruksi sangatlah kompleks. Pada suatu proyek infrastruktur berskala besar, risiko dan kewajiban secara teoritis harus dibagi secara adil di antara para pihak pengaturan secara kontraktual yang biasanya menggunakan FIDIC Condtions of Contract. Walaupun demikian, untuk menghindari risiko yang tidak diperkirakan sebelumnya dan menghindari terjadinya sengketa selama pelaksanaan, kontraktor baik nasional maupun internasional harus 
menaruh perhatian pada karakterisitik lokal dan praktek-praktek kontrak setempat. (Sarwono, 2014 : 19).

Penggunaan SSUK konstruksi di sektor publik, yang masih merupakan suatu citacita stakeholder bidang jasa konstruksi, secara legal sebenarnya dimungkinkan, seperti dinyatakan dalam Undang-Undang No 2 Tahun 2017 Tentang Jasa Konstruksi, Bab 1 Ketentuan Umum, Pasal 1 butir 8 yang manyatakan : "Kontrak Kerja Konstruksi adalah keseluruhan dokumen kontrak yang mengatur hubungan hukum antara Pengguna Jasa dan Penyedia Jasa dalam penyelenggaraan Jasa Konstruksi".

\section{Faktor-faktor Penyebab Klaim Konstruksi di Indonesia}

Klaim dianggap sebagai salah satu item terpenting yang dapat menyebabkan efek berbahaya bagi organisasi dan industri konstruksi. Pengajuan klaim telah menjadi praktik umum dan fitur penting dalam banyak proyek konstruksi. Klaim dapat sering terjadi di proyek besar dan dapat menyebabkan kesulitan anggaran bagi Owner. Mereka dapat menyebabkan kesulitan keuangan, pembatasan arus kas, dan hilangnya likuiditas kepada kontraktor. Memahami penyebab klaim sangat penting untuk menghindari atau mengurangi klaim dalam industri konstruksi.

Klaim konstruksi menurut Sarwono (2011) terjadi karena adanya dua hal, yaitu keinginan (desire) dan kesempatan (chance). Penelitian oleh Sarwono (2014), pada proyek-proyek jalan dan jembatan di lingkungan Kementrian Pekerjaan Umum, didapat hasil bahwa penyebab klaim tertinggi adalah changes in design diikuti oleh inefficiency and disruption berada di peringkat atas. Disamping itu masuknya changing in laws and regulations menjadi salah satu penyebab dominan. Di luar faktor- faktor di atas, terdapat suatu faktor baru, yaitu slow decision making of the employer, yang ternyata tidak disebabkan oleh tidak kompetennya petugas proyek, tetapi lebih disebabkan oleh kekhawatiran adanya langkah "kriminalisasi".

\section{Metodologi Penelitian}

Penelitian ini adalah yang pertama kali dilakukan mengenai analisis perbandingan model kontrak APBN dan APBD terhadap model kontrak FIDIC dengan focus pada infrastuktur small scale dan menggunakan dasar hukum UU no 2 Tahun 2017 tentang Jasa Konstruksi. Metode penelitian menggunakan metode kualitatif dan kuantitatif, yang membandingkan penyebab klaim tertinggi dengan klausula-klausula terkait dalam Syarat-Syarat Umum Kontrak terhadap FIDIC General Conditions of Contract.

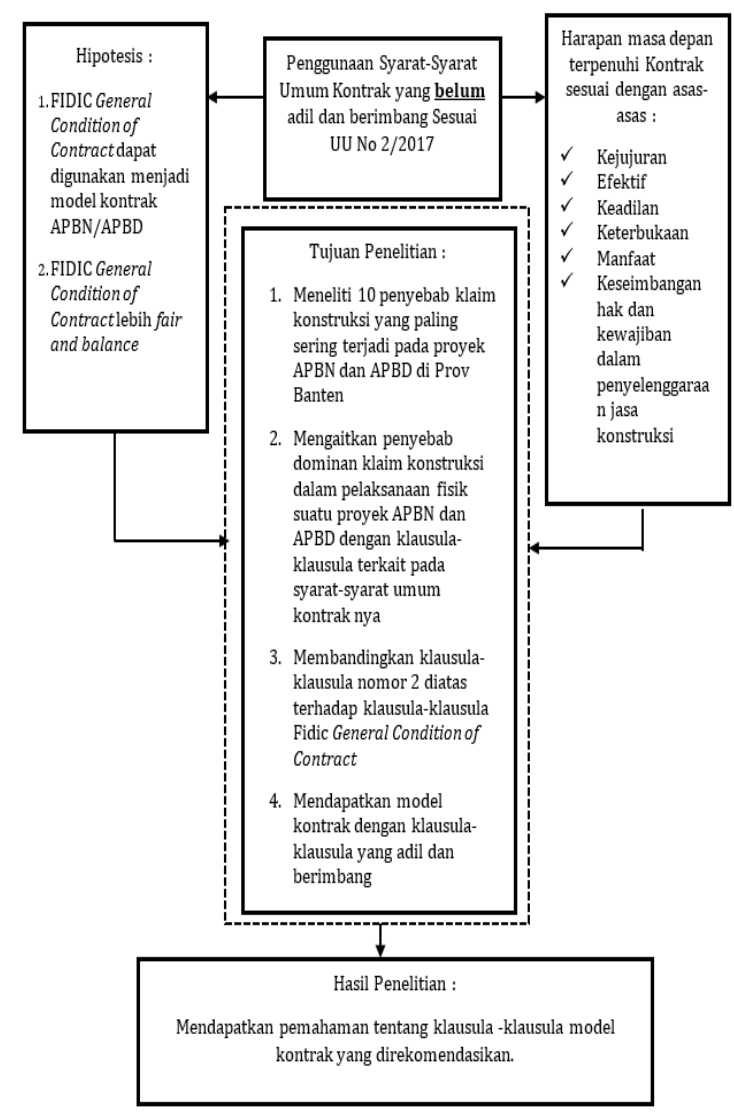

Gambar 1. Kerangka Pemikiran 
Berdasarkan hasil survey pendahuluan ternyata terdapat 25 variabel yang didapatkan melalui validitas content. Menurut Kerlinger (1990) validitas content adalah validitas yang diperhitungkan melalui pengujian terhadap isi alat ukur dengan analisis rasional. Pertanyaan yang dicari adalah "sejauh mana item-item dalam suatu alat ukur mencakup keseluruhan isi objek yang hendak diukur oleh alat ukur yang bersangkutan, atau berhubungan dengan representasi dari keseluruhan lingkungan sekitar.

\section{Tabel 1. Variabel Penelitian} Berdasarkan Survey Pendahuluan

\begin{tabular}{|c|c|l|}
\hline No & $\begin{array}{c}\text { No } \\
\text { Faktor }\end{array}$ & $\begin{array}{c}\text { Faktor-Faktor Penyebab Terjadinya Klaim } \\
\text { Konstruksi di Provinsi Banten }\end{array}$ \\
\hline 1 & A1 & Possession of Site and Availability \\
\hline 2 & A2 & Changes in Design \\
\hline 3 & A3 & Oral Changes Order by Employer \\
\hline 4 & A4 & Slow Decision Making Of The Employer \\
\hline 5 & A5 & Inadequate Site Investigation \\
\hline 6 & A6 & Contractor Late Completion \\
\hline 7 & A7 & Suspension Of Work \\
\hline 8 & A8 & Delayed Caused By The Employer \\
\hline 9 & A9 & Delayed Caused By The Contractor \\
\hline 10 & A10 & Late Drawing \& Instruction Approval \\
\hline 11 & A11 & Changes In Scope Of Work \\
\hline 12 & B1 & Unforeseeable Physical Condition \\
\hline 13 & B2 & Subsurface Condition Geology \\
\hline 14 & C1 & Ineffisiency And Disruption \\
\hline 15 & C2 & Productivity of Equipment \\
\hline 16 & C3 & Productivity of Labour \\
\hline 17 & C4 & Lack of Communication Among Parties \\
\hline 18 & D1 & Ambiguisties In Contract Document \\
\hline 19 & D2 & Different Interpretation Of Contract Document \\
\hline 20 & D3 & Constructive Change Order \\
\hline 21 & D4 & Variation Order \\
\hline 22 & D5 & Delayed Payment On Contract \& Extras \\
\hline 23 & E1 & Changes In Law \& Regulation \\
\hline 24 & E2 & Government Policies \\
\hline 25 & E3 & Cultural Diffrence \\
\hline & & \\
\hline 12
\end{tabular}

Metode analisis yang digunakan dalam penelitian ini menggunakan Relative Importance Index (RII) dan Multistep Interdependent Desktop. RII menurut (Johnson, 2001) adalah merupakan metode peramalan penting dalam regresi berganda dan mengevaluasi langkah-langkah alternatif yang dinilai relatif penting. Analisis dominasi dan bobot relatif menjadi langkah yang paling sukses dari kepentingan relatif yang tersedia.

Persamaan 1. Analisis Data Menggunakan Relative Importance Index (RII)

$$
R I I=\frac{\sum P j U j}{N(n)}
$$

Dimana :

$\begin{array}{ll}R I I & \text { : Relative Importance Index } \\ P j & \quad \text { : Rating Responden penyebab } \\ & \text { faktor klaim } \\ \text { Uj } & \text { : jumlah responden menempatkan } \\ & \text { identik bobot / rating } \\ & \text { pada penyebab faktor klaim } \\ N & \text { : Ukuran Sampel } \\ n & \text { : skor tertinggi yang dicapai } \\ & \text { pada penyebab faktor klaim }\end{array}$

Analisis perbandingan klausula-klausula SSUK terhadap FIDIC GCC menggunakan Metode Multistep Interdependent Desktop.

\section{Lokasi Penelitian}

Penelitian ini berlokasi di daerah Kabupaten Serang, Kota Serang, Kabupaten Pandeglang, Kabupaten Lebak, Kabupaten Tangerang di Provinsi Banten.

\section{Populasi dan Sampel Penelitian}

Populasi dan sampel pada tahap penelitian ini adalah para pengelola lima (5) proyek APBN tahun anggaran 2019 di lingkungan Balai Besar Wilayah Sungai CiujungCidanau-Cidurian (BBWSC3) Prov.Banten, Balai Prasarana Permukiman Wilayah Banten dan lima (5) proyek APBD Tahun Anggaran 2019 di lingkungan Dinas Pekerjaan Umum dan Penataan Ruang (PUPR) Provinsi Banten, Dinas Perumahan dan Kawasan Permukiman (PRKP) Provinsi Banten. Dengan jumlah responden sebanyak 37 orang. 


\section{Jenis Data}

Data yang diperlukan adalah data primer dan data sekunder.

1. Data primer

Data yang diperoleh dengan menyebarkan kuesioner kepada responden, selain itu melakukan wawancara langsung terhadap stakeholder.

2. Data sekunder

Data yang didapat dari sepuluh (10) kontrak APBN dan APBD, serta literatur-literatur yang berkaitan dengan penelitian ini.

\section{Analisis dan Pembahasan}

Dalam tahap ini uji RII dilakukan untuk mengetahui berapa besar pengaruh faktorfaktor yang telah di peroleh dan diuji kevalidan serta reliabilitasnya. Uji RII ini juga mempermudah peneliti untuk mengetahui faktor-faktor penyebab klaim konstruksi yang mempunyai nilai tertinggi sampai terendah. Berikut ini salah satu contoh perhitungan nilai RII untuk variabel

(A1) :

Diketahui :

$\Sigma$ PiUi : Jumlah/total jawaban 37 responden untuk variabel $\mathrm{A} 1=176$

$\mathrm{N}$ : Jumlah responden $=37$

$\mathrm{N}$ : Skor tertinggi yang dapat dicapai pada penyebab Ketersediaan lahan kerja $=5$

Sehingga diperoleh :

$\Sigma$ PiUi/ $\mathrm{N}$ x $\mathrm{n}=176 /(37 \times 5)=0,9514=$ $95,14 \%$

Uji RII yang diterapkan terhadap 37 (tiga puluh tujuh) responden dengan 25 (dua puluh lima) variabel diproses dengan menggunakan aplikasi Microsoft Excel. Untuk penghitungan secara menyeluruh dan terperinci dapat dilihat secara lengkap pada tabel 2.
Tabel 2. RII Dari sisi Pengguna Jasa Untuk Faktor-Faktor Penyebab Klaim di Provinsi Banten

\begin{tabular}{|c|c|c|c|c|c|}
\hline $\begin{array}{c}\text { No } \\
\text { No Faktor } \\
\end{array}$ & \begin{tabular}{|l|} 
Faktor-Faktor Penyebab Terjadinya \\
Klaim Kosntrukksi di Provinsi Banten \\
\end{tabular} & Skor & Mean & $\operatorname{RII}(\%)$ & Rank \\
\hline $1 \quad \mathrm{~A} 1$ & Possession of site and availability & 176 & 4,7568 & 95,14 & 1 \\
\hline $2 \quad \mathrm{D} 1$ & Ambiguisties In Contract Document & 167 & 4,5135 & 90,27 & 2 \\
\hline $3 \quad \mathrm{~A} 2$ & Changes in design & 161 & 4,3514 & 87,03 & 3 \\
\hline $4 \quad$ A11 & Changes In Scope Of Work & 160 & 4,3243 & 86,49 & 4 \\
\hline $5 \quad$ A9 & Delayed Caused By The Contractor & 153 & 4,1351 & 82,70 & 5 \\
\hline A6 & Contractor Late Completion & 153 & 4,1351 & 82,70 & 6 \\
\hline D2 & $\begin{array}{l}\text { Different Interpretation Of Controct } \\
\text { Document }\end{array}$ & 150 & 4,0541 & 81,08 & 7 \\
\hline $8 \quad D 4$ & Variation Order & 149 & 4,0270 & 80,54 & 8 \\
\hline $9 \quad \mathrm{~A} 7$ & Suspension of Work & 149 & 4,0270 & 80,54 & 9 \\
\hline $10 \mathrm{~B} 1$ & Unforesseable Physical Condition & 142 & 3,8378 & 76,76 & 10 \\
\hline $11 \quad \mathrm{E} 2$ & GovernmentPolicies & 140 & 3,8378 & 75,68 & 11 \\
\hline $12 \quad B 2$ & Subsurface Condition Geology & 140 & 3,7838 & 75,68 & 12 \\
\hline $13 \quad \mathrm{~A} 10$ & Late Drawing \& Instruction Approval & 132 & 3,5676 & 71,35 & 13 \\
\hline $14 \quad \mathrm{E} 1$ & Changes In Law \& Regulation & 131 & 3,5405 & 70,81 & 14 \\
\hline $15 \quad$ D3 & Constructive Change Order & 129 & 3,4865 & 69,73 & 15 \\
\hline $16 \quad A 8$ & Delayed Caused By The Employer & 126 & 3,4054 & 68,11 & 16 \\
\hline $17 \quad \mathrm{~A} 5$ & Inadequate Site Investigation & 123 & 3,3243 & 66,49 & 17 \\
\hline $18 \quad \mathrm{Cl}$ & Ineffisiency And Disruption & 123 & 3,3243 & 66,49 & 18 \\
\hline $19 \quad \mathrm{D} 5$ & Delayed Payment On Contract \& Extras & 122 & 3,2973 & 65,95 & 19 \\
\hline $20 \quad \mathrm{E} 3$ & Cultural Diffrence & 116 & 3,1351 & 62,70 & 20 \\
\hline $21 \quad 33$ & Productivity of Labour & 116 & 3,1351 & 62,70 & 21 \\
\hline $22 \quad \mathrm{~A} 4$ & Slow Decision Making Of The Employer & 116 & 3,1351 & 62,70 & 22 \\
\hline $23 \quad C 4$ & Lack of communication among parties & 114 & 3,0811 & 61,62 & 23 \\
\hline $24 \quad C 2$ & Productivity of equipment & 111 & 3,0000 & 60,00 & 24 \\
\hline $25 \quad A 3$ & Oral Changes order by employer & 107 & 2,8919 & 57,84 & 25 \\
\hline
\end{tabular}

Tabel 3. Sepuluh (10) tertinggi penyebab klaim konstruksi di Provinsi Banten

\begin{tabular}{|c|c|c|c|}
\hline No & $\begin{array}{c}\text { Faktor-Faktor Penyebab Terjadinya Klaim } \\
\text { Konstruksi di Provinsi Banten }\end{array}$ & $\begin{array}{l}\text { RII } \\
(\%)\end{array}$ & Rank \\
\hline (1) & $\begin{array}{l}\text { Ketersediaan dan kepemilikan lahan kerja } \\
\text { (Possession of site and availability) }\end{array}$ & 95,14 & 1 \\
\hline (2) & $\begin{array}{l}\text { Ambigu dalam memaknai klausula kontrak } \\
\text { (Ambiguities in contract documents) }\end{array}$ & 90,27 & 2 \\
\hline (3) & Perubahan desain (Changes in design) & 87,03 & 3 \\
\hline (4) & $\begin{array}{l}\text { Perubahan cakupan pekerjaan } \\
\text { (Changes in scope of work) }\end{array}$ & 86,49 & 4 \\
\hline (5) & $\begin{array}{l}\text { Keterlambatan dikarenakan kontraktor } \\
\text { (Delayed caused by the contractor) }\end{array}$ & 82,70 & 5 \\
\hline (6) & $\begin{array}{l}\text { Kontraktor terlambat menyelesaikan } \\
\text { pekerjaan (Contractor's late completion) }\end{array}$ & 82,70 & 6 \\
\hline (7) & $\begin{array}{l}\text { Perbedaan interpretasi dokumen kontrak } \\
\text { (Different interpretation of contract } \\
\text { document) }\end{array}$ & 81,08 & 7 \\
\hline (8) & Perintah perubahan (Variations order) & 80,54 & 8 \\
\hline (9) & $\begin{array}{l}\text { Penghentian sementara pekerjaan } \\
\text { (Suspension of the works) }\end{array}$ & 80,54 & 9 \\
\hline$(10)$ & $\begin{array}{l}\text { Kondisi fisik yang tidak dapat diperkirakan } \\
\text { sebelumnya (Unforeseeable physical } \\
\text { condition) }\end{array}$ & 76,76 & 10 \\
\hline
\end{tabular}


Dari hasil analisis data kuesioner dengan menggunakan metode RII (Relative Important Index), didapat sepuluh (10) tertinggi penyebab klaim konstruksi di Provinsi Banten, seperti tertera pada tabel 2 diatas.

\section{Analisis Perbandingan Klausula- Klausula SSUK Terhadap FIDIC GCC}

Ketersediaan dan Kepemilikan Lahan Kerja (Possession of site and availability) didapat hasil analisis sebagai berikut.

1) Pada SSUK, penyerahan lokasi kerja yang gagal dipenuhi oleh pengguna jasa pada Sub-Klausul 19.5 berdampak peristiwa kompensasi pada Sub-Klausul 64.1d, yang sebelumnya harus ada peringatan sesegera mungkin dari penyedia jasa kepada pengawas pekerjaan (Sub-Klausul 30.1). Pada SSUK tidak disebutkan jangka waktu kontraktor menyampaikan peringatan dini, sedangkan pada FIDIC GCC disebutkan tidak lebih dari 28 hari. Pada SSUK tidak disebutkan jangka waktu konsultan harus menjawab klaim dari kontraktor, sedangkan pada FIDIC GCC disebutkan maksimal 42 hari setelah menerima suatu klaim maka konsultan harus memberikan tanggapan apakah menyetujui atau menolak dengan memberikan keterangan/penjelasan secara detil.

2) Pada SSUK, Peristiwa Kompensasi SubKlausul 64.1d menjadi tanggung jawab penuh PPK, yang disebabkan tidak jelasnya peran konsultan pada Peringatan Dini Sub-Klausul 30.1, dimana pada sub-klausul ini tidak disebutkan pengawasan pekerjaan untuk menindaklanjuti peringatan dari kontraktor. Sedangkan pada FIDIC GCC, pada Sub_Klausul 20.1 peran pengguna jasa sudah di "bentengi" oleh konsultan yang menindaklanjuti dengan menyetujui atau menolak klaim yang diajukan kontraktor dalam jangka waktu maksimal 42 hari setelah menerima klaim.

3) Pada SSUK, pengguna jasa/pejabat pembuat komitmen mempunyai kewajiban memberikan lokasi kerja sesuai dengan keperluan kontraktor yang tertera dalam rencana pekerjaan yang disetujui oleh kedua pihak dalam rapat awal sebelum penandatangan kontrak. (Rencana kerja yang diberikan kontraktor kemungkinan besar bisa berubah, tidak sesuai dengan yang dibuat pada saat melakukan penawaran) Sedangkan pada FIDIG GCC owner harus memberikan kepada penyedia jasa hak untuk memasuki dan menguasai lokasi kerja dalam waktu yang sesuai dengan Lampiran Penawaran. (Rencana kerja sesuai dengan penawaran).

Ambigu dalam memaknai klausula kontrak (Ambiguisties in contract document) didapat hasil analisis sebagai berikut.

1) Pada SSUK Klausula 30 Peringatan Dini, Sub-Klausula 30.1 ada beberapa kata dan frasa yang ambigu dan hal ini dapat menimbulkan perselisihan sendiri. Seperti frasa "sedini mungkin", frasa ini tidak mempunyai time frame yang jelas. Sedangkan pada pada FIDIC GCC time frame itu lebih jelas, bahwa ada batas waktu penyampaian klaim yaitu tidak lebih dari 28 hari.

2) Pada SSUK Klausula 30 Peringatan Dini, Sub-Klausula 30.1 ini tidak dijelaskan tugas konsultan secara detil setelah mendapatkan peringatan dari kontraktor sehingga menjadi kabur makna dari Sub-Klausula 30.1 ini. Sedangkan pada pada FIDIC GCC SubKlausula 20.1 dijelaskan bahwa 
konsultan harus menetapkan dan menyetujui atau menolak klaim yang dilakukan kontraktor paling lama 42 hari setelah menerima klaim dari kontraktor, hal ini bermakna ada kepastian bagi kontraktor atas klaimnya.

3) Pada SSUK Klausula 30 Peringatan Dini, Sub-Klausula 30.1 kalimat ini, "Pengawas pekerjaan dapat memerintahkan penyedia untuk menyampaikan secara tertulis...", bermakna bahwa penyedia jasa/kontraktor boleh saja menyampaikan klaim secara lisan, apabila hal ini terjadi tentu akan menimbulkan perselisihan lain di kemudian hari. Sedangkan pada FIDIC GCC Sub-Klausula 20.1 tegas dikatakan bahwa semua klaim yang diajukan kontraktor harus berbentuk catatan tertulis yang terdokumentasikan dengan baik, yang setiap saat bisa diperiksa oleh konsultan.

Perubahan desain (Changes in design), Perubahan cakupan pekerjaan (Changes in scope of work), Perintah perubahan (Variations order) didapat hasil analisis sebagai berikut.

1) Pada SSUK Klausula sub-klausul 35.1 perintah perubahan berasal dari PPK/pengguna jasa. Pada FIDIC GCC sub-klausul 13.1 perintah perubahan berasal dari konsultan.

2) Pada SSUK Klausula sub-klausul 35.1 perubahan pekerjaan terkait desain dilaksanakan kontraktor bersama-sama penyedia jasa. Pada FIDIC GCC subklausul 13.1 perubahan pekerjaan terkait desain dilaksanakan oleh kontraktor, apabila kontraktor tidak mampu melakukan hal ini disampaikan kepada konsultan didukung dengan bukti-bukti, maka konsultan dapat membatalkan, menetapkan atau mengubah instruksi.

3) Pada SSUK sub-klausul 35.5 perubahan pekerjaan yang mengakibatkan biaya kontrak bertambah, dibatasi maksimal $10 \%$ (sepuluh persen) dari harga kontrak awal dan tergantung dari ketersediaan anggaran. Pada FIDIC Conditions of Contract apabila ada penyesuaian harga kontrak dikarenakan adanya variasi, maka ditentukan melalui rumus. Rumus ini ada pada sub-klausul 13.8, sebagai berikut: "Pn"=a+b Ln/Lo"+" c Ec/Eo+d $\mathrm{Mn} / \mathrm{Mo}$.

Keterlambatan dikarenakan kontraktor (Delayed caused by the contractor), Kontraktor terlambat menyelesaikan pekerjaan (Contractor late completion) didapat hasil analisis sebagai berikut.

1) Pada SSUK sub-klausul 44.1 apabila penyedia terlambat melaksanakan pekerjaan, maka PPK harus mengeluarkan peringatan secara tertulis atau memberlakukan kontrak kritis. Pada FIDIC GCC sub-klausul 8.6, apabila kontraktor terlambat maka konsultan dapat menginstruksikan kepada kontraktor untuk melakukan revisi rencana kerja dan apabila metoda yang di revisi tersebut mengakibatkan pengguna jasa mengeluarkan tambahan biaya, kontraktor berdasarkan sub-klausula 2.5 [klaim oleh pengguna jasa] harus membayar biaya tersebut kepada pengguna jasa.

2) Pada SSUK sub-klausul 44.2, apabila kontraktor terlambat dan dinyatakan oleh PPK kontrak kritis, kontraktor diberikan kesempatan untuk mengejar ketertinggalan jadwal penyelesaian pekerjaan dengan melalui 3 (tiga) kali tahapan rapat pembuktian (show cause 
meeting), seperti termuat dalam subklausul 44.3, dan apabila kontraktor gagal menyelesaikan pekerjaan sampai masa pelaksanaan berakhir, namun PPK menilai kontraktor mampu menyelesaikan pekerjaan (Klausul 45. Pemberian Kesempatan), maka PPK dapat memberikan kesempatan kepada kontraktor untuk menyelesaikan pekerjaan dengan sanksi denda keterlambatan. Pada FIDIC GCC subklausul 8.7, apabila kontraktor gagal memenuhi sub-klausul 8.2 [waktu penyelesaian], kontraktor berdasarkan sub-klausul 2.5 [klaim oleh pengguna jasa] harus membayar denda keterlambatan atas kegagalan tersebut.

3) Pada SSUK sub-klausul 44.3, PPK dapat memutus kontrak secara sepihak apabila penyedia gagal pada rapat pembuktian ke 3 setelah kontrak dinyatakan kritis. Pada FIDIC GCC subklausul 15.2 apabila kontraktor tanpa alasan yang jelas gagal melanjutkan pekerjaan sesuai dengan klausula 8 [tanggal mulai pekerjaan, keterlambatan dan penghentian sementara] atau gagal memenuhi pemberitahuan yang dikeluarkan subklasul 7.5 [penolakan] atau sub-klausul 7.6 [perbaikan pekerjaan], dalam jangka waktu 28 hari setelah menerima pemberitahuan itu, maka pengguna jasa dapat melakukan pemutusan kontrak.

Penghentian pekerjaan (Suspension of the works) didapat hasil analisis sebagai berikut.

1) Pada SSUK Klausul 28 penundaan dapat dilakukan oleh pengawas pekerjaan dengan laporan ditembuskan kepada PPK. Pada Model Kontrak FIDIC General Condition of Contract sub-klausul 8.8 konsultan dapat setiap saat menginstruksikan kontraktor untuk menghentikan kemajuan suatu bagian dari pekerjaan atau seluruh pekerjaan, dengan menyampaikan alasan penghentian pekerjaan.

2) Pada SSUK tidak ada klausul mengenai konsekuensi dari penghentian pekerjaan. Pada FIDIC General Condition of Contract dijelaskan secara detil mengenai konsekuensi penghentian pekerjaan ini seperti tercantum pada sub-klausul 8.9 [konsekuensi penghentian], subklausul 8.10 [pembayaran untuk instalasi mesin dan bahan-bahan pada saat Penghentian], dan sub-klausul 8.11 [penghentian yang berkepanjangan].

3) Pada sub-klausul 38.7 SSUK Model Kontrak APBN dan APBD, kontrak pekerjaan dapat dihentikan sementara karena keadaan kahar dan dapat dihentikan secara permanen apabila karena kahar pekerjaan tidak dapat dilanjutkan/diselesaikan. Pada Model Kontrak FIDIC General Condition of Contract keadaan kahar dijabarkan pada Klausul 19 [keadaan kahar], selain itu pada FIDIC GCC dijelaskan secara khusus untuk subkontraktor yang terkena dampak akibat keadaan kahar yakni pada sub-klausul 19.5 [keadaan kahar yang mempengaruhi subkontraktor].

Kondisi fisik yang tidak dapat diperkirakan sebelumnya (Unforeseeable physical condition) didapat hasil analisis sebagai berikut.

1) Kondisi fisik yang tidak dapat diperkirakan sebelumnya ini pada SSUK Model Kontrak APBN dan APBD diatur pada Klausul 35 Sub-Klausula 35.1," Dalam hal terdapat perbedaan antara kondisi lapangan pada saat pelaksanaan dengan gambar dan/atau spesifikasi teknis yang ditentukan dalam dokumen kontrak, PPK bersama penyedia dapat 
melakukan perubahan pekerjaan". Pada FIDIC GCC, kondisi fisik yang tidak dapat diperkirakan sebelumnya ini diatur dalam sub-klasul khusus dengan nama yang sama yaitu Sub-Klausul 4.12 (kondisi fisik yang tidak dapat diperkirakan sebelumnya).

2) Pada SSUK, apabila karena hal kondisi fisik yang tidak dapat diperkirakan sebelumnya ini, PPK memerintahkan untuk mengatasi kondisi tertentu yang tidak dapat diduga sebelumnya yang disebabkan/tidak disebabkan oleh PPK, maka kontraktor berhak mendapat kompensasi seperti diatur dalam peristiwa kompensasi, Klausula 64. SubKlausul 64.1. Sedangkan pada FIDIC GCC Sub-Klausul 4.12 [kondisi fisik yang tidak dapat diperkirakan sebelumnya] apabila kondisi fisik yang tidak dapat diperkirakan sebelumnya ini menimbulkan variasi pekerjaan, maka konsultan akan menetapkan untuk menyetujui atau menetapkan pengurangan biaya yang belaku untuk kondisi ini. Konsultan harus mempertimbangkan seluruh bukti kondisi fisik yang diperkirakan sebelumnya oleh kontraktor ketika memasukkan penawaran, data tersebut dapat disediakan oleh kontraktor, tetapi tidak terikat pada bukti-bukti tersebut. Rekapitulasi analisis perbandingan klausula-klausula SSUK terhadap FIDIC GCC terkait sepuluh (10) tertinggi penyebab klaim konstruksi di Provinsi Banten pada tabel 4 di bawah ini.
Tabel 4. Rekapitulasi Perbandingan Klausula-Klausula SSUK Terhadap FIDIC GCC

\begin{tabular}{|c|c|c|c|}
\hline No & $\begin{array}{l}\text { Analisis Perbandingan Terkait } 10 \\
\text { Tertinggi Penyebab Klaim } \\
\text { Konstruksi di Provinsi Banten }\end{array}$ & SSUK & GCC \\
\hline (1) & $\begin{array}{l}\text { Ketersediaan dan kepemilikan lahan } \\
\text { kerja (Possession of site and } \\
\text { availability) }\end{array}$ & Klausul.19 & $\begin{array}{l}\text { Sub- } \\
\text { Klausul } \\
2.1\end{array}$ \\
\hline $\begin{array}{l}\text { (2) \& } \\
\text { (7) }\end{array}$ & $\begin{array}{l}\text { Ambigu dalam memaknai klausula } \\
\text { kontrak (Ambiguities in contract } \\
\text { documents), Perbedaan interpretasi } \\
\text { dokumen kontrak (Different } \\
\text { interpretation of contract document) }\end{array}$ & $\begin{array}{l}\text { Klausul } \\
30 .\end{array}$ & $\begin{array}{l}\text { Sub- } \\
\text { Klausul } \\
20.1\end{array}$ \\
\hline $\begin{array}{l}\text { (3), } \\
(4), \& \\
(8)\end{array}$ & $\begin{array}{l}\text { Perubahan desain (Changes in } \\
\text { design), Perubahan cakupan } \\
\text { pekerjaan } \\
\text { (Changes in scope of work), Perintah } \\
\text { perubahan (Variations order) }\end{array}$ & $\begin{array}{l}\text { Klausul } \\
35 .\end{array}$ & $\begin{array}{l}\text { Sub- } \\
\text { Klausul } \\
13.1 \\
13.2 \\
13.3 \\
\end{array}$ \\
\hline $\begin{array}{l}\text { (5) \& } \\
\text { (6) }\end{array}$ & $\begin{array}{l}\text { Keterlambatan dikarenakan } \\
\text { kontraktor } \\
\text { (Delayed caused by the contractor) } \\
\text { Kontraktor terlambat menyelesaikan } \\
\text { pekerjaan (Contractor's late } \\
\text { completion) }\end{array}$ & $\begin{array}{l}\text { Klausul } \\
\text { 44. dan } \\
\text { Klausul } \\
45 .\end{array}$ & $\begin{array}{l}\text { Sub- } \\
\text { Klausul } \\
8.6,8.7 \\
15.1 \\
15.2\end{array}$ \\
\hline (9) & $\begin{array}{l}\text { Penghentian sementara pekerjaan } \\
\text { (Suspension of the works) }\end{array}$ & $\begin{array}{l}\text { Klausul } \\
\text { 28. Dan } \\
\text { Klausul } \\
38 .\end{array}$ & $\begin{array}{l}\text { Sub- } \\
\text { Klausul } \\
8.8,8.9, \\
8.11 \\
19.4\end{array}$ \\
\hline$(10)$ & $\begin{array}{l}\text { Kondisi fisik yang tidak dapat } \\
\text { diperkirakan sebelumnya } \\
\text { (Unforeseeable physical condition) }\end{array}$ & $\begin{array}{l}\text { Sub- } \\
\text { Klausul } \\
35.1 \text { dan } \\
\text { Sub- } \\
\text { Klausul } \\
64.1\end{array}$ & $\begin{array}{l}\text { Sub- } \\
\text { Klausul } \\
4.12\end{array}$ \\
\hline
\end{tabular}

\section{Kesimpulan}

1. Dari hasil analisis data kuesioner dengan menggunakan metode RII (Relative Important Index) didapat sepuluh (10) tertinggi penyebab klaim konstruksi di Provinsi Banten, yaitu : 1) ketersediaan dan kepemilikan lahan kerja (possession of site and availability), 2) ambigu dalam memaknai klausula kontrak (ambiguities in contract documents), 3) perubahan desain (changes in design), 4) perubahan cakupan pekerjaan (changes in scope of work), 5) keterlambatan dikarenakan kontraktor (delayed caused by the contractor), 6) kontraktor terlambat menyelesaikan pekerjaan (contractor's late completion), 7) perbedaan 
interpretasi dokumen kontrak (different interpretation of contract document), 8) perintah perubahan (variations order), 9) penghentian sementara pekerjaan (suspension of the works), 10) kondisi fisik yang tidak dapat diperkirakan sebelumnya (unforeseeable physical condition).

2. Analisis perbandingan antara SyaratSyarat Umum Kontrak (SSUK) model Kontrak APBN dan APBD terhadap model kontrak FIDIC General Conditions of Contract (GCC) terkait sepuluh (10) tertinggi penyebab klaim konstruksi di Provinsi Banten, yaitu : 1) ketersediaan dan kepemilikan lahan kerja (possession of site and availability), pada SSUK Klausul.19 berbanding FIDIC GCC SubKlausul 2.1,2) ambigu dalam memaknai klausula kontrak (ambiguities in contract documents), perbedaan interpretasi dokumen kontrak (different interpretation of contract document), pada SSUK Klausul 30. berbanding FIDIC GCC Sub-Klausul 20.1, 3) perubahan desain (changes in design), perubahan cakupan pekerjaan (changes in scope of work), dan perintah perubahan (variations order) pada SSUK Klausul 35. berbanding FIDIC GCC SubKlausul 13.1, 13.2, 13.3, 4) keterlambatan dikarenakan kontraktor (delayed caused by the contractor), kontraktor terlambat menyelesaikan pekerjaan (contractor's late completion) pada SSUK Klausul 44. dan Klausul 45. berbanding FIDIC GCC Sub-Klausul 8.6, 8.7, 15.1, 15.2, 5) penghentian sementara pekerjaan (suspension of the works) pada SSUK Klausul 28. Dan Klausul 38. berbanding FIDIC GCC SubKlausul 8.8, 8.9, 8.11, 19.4, 6) Kondisi fisik yang tidak dapat diperkirakan sebelumnya (unforeseeable physical condition) pada SSUK Sub-Klausul 35.1 dan Sub-Klausul 64.1 berbanding FIDIC GCC Sub-Klausul 4.12.

3. Hasil analisis perbandingan menunjukkan bahwa model kontrak FIDIC General Conditions of Contract dapat dipergunakan sebagai Model kontrak untuk kegiatan konstruksi yang didanai oleh APBN dan APBD.

4. Klausula-klausula pada model kontrak FIDIC General Conditions of Contract lebih komprehensif (comprehensive), adil (fair) dan berimbang (balance) dalam mengantisipasi kemungkinan terjadinya klaim konstruksi baik dari pihak pengguna jasa maupun penyedia jasa.

\section{Daftar Pustaka}

Abdul-Malak, M. A. U., Hanano, H. F., \& Turman, H. M. (2019). Administration Impairments Resulting from Imbalanced Contract Conditions: Owner Payment Default.Journal of Legal Affairs and Dispute Resolution in Engineering and Construction, 11(4), 05019003.

Aktuğ, F. P. (2012). Comparison of FIDIC conditions of contract (1999) and UNCITAL legal guide from prospective disputes and claims perspectives (Master's thesis).

Albahar, I. A. (2018). Comparison Grounds for Construction Contracts Termination under UAE Law and FIDIC Standard Contracts (Doctoral dissertation, The British University in Dubai (BUiD)).

Andriaanse, Jhon (2010). Construction Contract Law : The Essentials, Palgrave, McMilan London, UK.

Besaiso, H., Fenn, P., Emsley, M., \& Wright, D. (2018). A comparison of the suitability of FIDIC and NEC conditions of contract in Palestine. Engineering, Construction and Architectural Management. 
El-Adaway, I. H., Abotaleb, I. S., Eid, M. S., May, S., Netherton, L., \& Vest, J. (2018). Contract administration guidelines for public infrastructure projects in the United States and Saudi Arabia: Comparative analysis approach. Journal of construction engineering and management, 144(6), 04018031.

Ezeldin, A. S., \& Abu Helw, A. (2018). Proposed Force Majeure Clause for Construction Contracts under Civil and Common Laws. Journal of Legal Affairs and Dispute Resolution in Engineering and Construction, 10(3), 04518005.

Fawzy, S. A., El-Adaway, I. H., PerreauSaussine, L., Abdel Wahab, M. S., \& Hamed, T. H. (2019). Civil law context for understanding employer's payment obligations under common law FIDIC. Journal of Legal Affairs and Dispute Resolution in Engineering and Construction, 11(1), 06518006.

Hamid, K. A., Soegiarso, R., Hardjomuljadi, S., Setiawan, M. I., Abdullah, D., \& Napitupulu, D. (2018, November). Model of Organizational Effectiveness Project Management on Infrastructure Development in Ministry of Public Works and Housing Republic of Indonesia. In Journal of Physics: Conference Series (Vol. 1114, No. 1, p. 012129). IOP Publishing.

Hardjomuljadi, Sarwono, Abdulkadir, Ariono dan Takei, Masaru (2006). Strategi Klaim Konstruksi Berdasarkan FIDIC Conditions of Contract, Polagrade, Jakarta.

Hardjomuljadi, Sarwono (2014), Permasalahan Klaim Konstruksi Di Proyek Institusi Pemerintah, di presentasikan pada Seminar Nasional 2014 Manajemen Klaim Proyek Konstruksi, Jakarta, 6 November 2014.
Hardjomuljadi, Sarwono (2014). Pengantar Kontrak Konstruksi (FIDIC Conditions of Contract), Kementerian Ristek Dikti, Kementerian PUPR, Universitas Mercu Buana dan Logoz Publishing. Bandung. Hardjomuljadi, Sarwono (2015). Manajemen Klaim Konstruksi (FIDIC Conditions of Contract), Kementerian Ristek Dikti, Kementerian PUPR, Universitas Mercu Buana dan Logoz Publishing. Bandung.

Hardjomuljadi, Sarwono (2016). Alternatif Penyelesaian Sengketa Konstruksi di Indonesia, Kementerian Ristek Dikti, Kementerian PUPR, Universitas Mercu Buana dan Logoz Publishing. Bandung. Johnson, J., \& Hardjomuljadi, S. (2019). Analisis Red Flag Clauses Pada FIDIC Rainbow 2017. Konstruksia, 10(2), 6788.

Li, S. (2018), Adaptation of Standard Contract Documents (FIDIC, AIA, EJCDC, Consensus Docs) in Chinese Construction, PM World Journal Vol. VII, Issue II February 2018.

Rasslan, N. D., \& Nassar, A. H. Comparing Suitability of NEC and FIDIC Contracts in Managing Construction Project in Egypt. Sanaky, A. T., Dundu, A. K., \& Lumeno, S. S. (2019). Model Strategi Perjanjian Kontrak Fidic Dan Kontrak Nasional Pada Kontraktor Ijo Dalam Proyek Infrastruktur Jalan Tol ManadoBitung. JURNAL SIPIL STATIK, 7(4).

Shafik, N., Qodsi, S., Serag, E., \& Helmi, M. (2016). Application of FIDIC contracts under the Egyptian civil code. Journal of Legal Affairs and Dispute Resolution in Engineering and Construction, 8(3), 04516004.

Shobana, K., Kumar, D. P., \& Kumar, J. S. (2014). Managing The Risks In Construction Project By Comparing MOSPI And FIDIC. 
Wibisono, A., \& Hardjomuljadi, S. (2018).

Analisis Pemilihan Model Kontrak FIDIC

Rainbow Contract 2017 Pekerjaan

Pembangunan Dermaga (Kajian Dari

Sudut Pandang Pengguna

Jasa). Konstruksia, 9(2), 15-24. 
